\title{
SISTEM REKOMENDASI PROFESI BERDASARKAN DIMENSI BIG FIVE PERSONALITY MENGGUNAKAN FUZZY INFERENCE SYSTEM TSUKAMOTO
}

\author{
Farhanna Mar'i ${ }^{1}$, Wayan Firdaus Mahmudy ${ }^{2}$, Cleoputri Yusainy ${ }^{3}$ \\ 1,2 Program Studi Magister Ilmu Komputer, Fakultas Ilmu Komputer, Universitas Brawijaya \\ ${ }^{3}$ Jurusan Psikologi, Fakultas Ilmu Sosial dan Ilmu Politik, Universitas Brawijaya \\ Email: ${ }^{1}$ farhannamar@student.ub.ac.id, ${ }^{2}$ wayanfm@ub.ac.id, ${ }^{3}$ cleoyusainy@ub.ac.id
}

(Naskah masuk: 19 Juli 2018, diterima untuk diterbitkan: 03 Juli 2019)

\begin{abstract}
Abstrak
Sistem rekomendasi dapat dimanfaatkan sebagai alat bantu untuk pengambilan keputusan. Pada sebuah perusahaan, sistem rekomendasi profesi bisa digunakan untuk menempatkan seorang karyawan pada posisi yang tepat. Pada penelitian ini diusulkan sistem rekomendasi profesi berdasarkan Big Five Personality traits yang meliputi Extraversion, Aggreableness, Conscentiousness, Neuroticm, dan Opennes. Input yang digunakan ialah parameter dimensi Big Five Personality yang dirumuskan oleh John. Metode yang digunakan adalah Fuzzy Inference System (FIS) Tsukamoto. Keakuratan sistem dihitung dengan membandingkan output sistem dengan dengan acuan Top Ranked Personality - Based Work Styles for 22 Job Families yang menghasilkan nilai akurasi sebesar $63 \%$.
\end{abstract}

Kata kunci: sistem rekomendasi profesi, big five personality, fis tsukamoto

\section{PROFESSION RECOMMENDATION SYSTEM BASED ON BIG FIVE PERSONALITY DIMENSION USING FUZZY INFERENCE SYSTEM TSUKAMOTO}

\begin{abstract}
Recommendation systems can be used as a tool for decision making. In a company, a professional recommendation system can be used to place an employee in the right position. In this study proposed system of professional recommendation based on Big Five Personality traits which includes Extraversion, Aggreableness, Conscentiousness, Neuroticm, and Opennes. The input used is the Big Five Personality dimension parameter formulated by John. The method used is Fuzzy Inference System (FIS) Tsukamoto. The accuracy of the system is calculated by comparing the output of the system with the reference Top Personality - Based Work Styles for 22 Job Families that produce an accuracy score of $63 \%$.
\end{abstract}

Keywords: profession recommendation system, big five personality, fis tsukamoto

\section{PENDAHULUAN}

Profesi merupakan domain yang sangat penting bagi kehidupan individu dewasa. "The right man, in the right place, at the right time, can steal millions," demikian petuah Gregory Nunn. Salah satu parameter klasik untuk menentukan kesesuaian pilihan profesi pekerjaan adalah ciri kepribadian. Studi terdahulu menyimpulkan bahwa kepribadian seseorang sangat terkait dengan kesuksesan karir baik secara ekstrinsik berupa gaji dan promosi maupun secara intrinsik berupa kepuasan terhadap pekerjaan (Seibert dan Kraimer, 2001). Kepribadian juga memiliki korelasi substansial dengan minat terhadap profesi yang berbeda-beda (Larson, Rottinhhaus, dan Borgen, 2002).

Bagi perusahaan pemberian posisi profesi karyawan pada tempat yang tepat erat hubungannya dengan kinerja karyawan sehingga dapat memberikan manfaat bagi perusahaan (Amaliyah dan Noviyanto,
2013). Sebuah sistem rekomendasi diperlukan untuk membantu merekomendasikan calon karyawan yang sesuai dengan sebuah profesi berdasarkan kepribadian yang dimiliki.

Goldberg, (1992) merumuskan pengelompokkan ribuan ciri sifat yang membedakan individu satu dengan yang lainnya menjadi 5 himpunan kepribadian yang selanjutnya disebut Big Five Personality, yaitu (1) Extraversion, ditandai dengan antusiasme dan kemampuan menjalin hubungan baik dengan orang lain, (2) Agreeableness, mempunyai ciri tulus dan fokus pada hal positif dan serta dapat dipercaya, (3) Conscientiousness, ciri yang menyukai keteraturan dan selalu disiplin dalam kesehariannya, (4) Neuroticism, yaitu pencemas atau emosi negatif seperti tegang atau khawatir, merupakan lawan dari Emotional Stability yang merupakan sifat dapat mengendalikan emosi secara stabil, dan (5) Openness merupakan sifat yang terbuka dan siap menghadapi perubahan, suka dengan hal yang baru. 
Inventori Kepribadian yang didasarkan pada Big Five Personality telah digunakan dalam penelitian sebelumnya di Indonesia untuk mengukur keterkaitan antara dimensi kepribadian dengan performansi kerja, komitmen organisasional, keberhasilan kewirausahaan, dan perilaku konsumen (Ramdhani, 2012). Input dari rekomendasi profesi ini ialah butir butir Big Five Personality oleh John (1990) dan telah diterjemahkan oleh beberapa peneliti sehingga dapat diadaptasi kedalam bahasa Indonesia. Dalam penelitian ini peneliti memilih inventori Big Five terjemahan dari Ramdhani (2012), dengan pertimbangan bahwa inventori ini bukan sekadar alih bahasa, namun juga disusun berdasarkan proses adaptasi budaya dan bahasa sehingga representatif terhadap konteks sosial budaya di Indonesia.

Adapun butir - butir Big Five Personality merupakan taksonomi kepribadian yang disusun berdasarkan pendekatan leksikal, yaitu sebuah cara untuk menggambarkan ciri individu yang dapat membedakannya dengan individu lainnya dengan mengelompokkan kalimat yang digunakan dalam keseharian (Ramdhani, 2012).

Untuk menentukan rekomendasi profesi yang tepat, dalam penelitian ini akan digunakan inventori Big Five Personality untuk mendapatkan nilai ukuran dimensi - dimensi Big Five yang ada pada seseorang dengan cara menggunakan pendekatan leksikal yang memiliki unsur ketidakpastian. Untuk memecahkan masalah ketidakpastian tersebut, diperlukan metode logika fuzzy yang bersifat fleksibel, dalam arti dapat beradaptasi dengan perubahan, dan ketidakpastian (Kusumadewi, 2013).

Sistem inferensi fuzzy yang akan digunakan ialah Tsukamoto. Kelebihan dari sistem inferensi Tsukamoto ini adalah dapat menyelesaikan masalah yang kompleks secara murni dari sebuah data (Wahyuni, Mahmudy, Iriany, 2016). Pada sistem rekomendasi profesi ini inferensi fuzzy Tsukamoto akan menggambarkan hubungan input dan output dengan aturan IF-THEN yang menghasilkan output jenis profesi dengan acuan Top Ranked Personality Based Work Styles for 22 Job Families (Sackett, 2014). Acuan tersebut merupakan 22 job families yang didapatkan dari O*NET Database yang telah dikaitkan dengan Big Five Personality.

\section{PENELITIAN TERKAIT}

Parewe dan Mahmudy, (2016) menggunakan metode FIS Tsukamoto untuk seleksi calon karyawan, yang menghasilkan tingkat akurasi sistem yang tinggi sebesar 0.61. Adapun input dalam sistem meliputi : tes tulis, tes keterampilan, tes wawancara, dan tes kesehatan dengan output sistem berupa keputusan hasil seleksi diterima, dan tidak diterima.

Mansyur dan Hartati, (2014) menggunakan metode FIS Tsukamoto pada sistem pakar diagnosis penyakit karies pada gigi dengan jumlah 14 data input, dan 2 ouput pada prototype sistem pakar tersebut yang menghasilkan 42 aturan yang digunakan untuk memetakan jenis karies gigi.

Wahyuni, Mahmudy, Iriany, (2016) mengimplementasikan FIS Tsukamoto pada peramalan curah hujan dengan menggunakan data curah hujan selama 10 hari, 20 hari, 170 hari, dan 340 hari sebelumnya yang menghasilkan tingkat akurasi menggunakan RMSE tertinggi sebesar 9.64, dan terendah sebesar 8.64.

Implementasi FIS Tsukamoto juga diimplementasikan pada penilaian prestasi kinerja pegawai dengan menggunakan 3 data input yang menghasilkan tingkat akurasi sistem sebesar $84 \%$ (Hadi dan Mahmudy, 2015).

Berdasarkan beberapa penelitian terkait menunjukkan bahwa FIS Tsukamoto terbukti cukup baik untuk masalah identifikasi dan klasifikasi. Oleh karena itu, penelitian ini merupakan penelitian baru dari implementasi FIS Tsukamoto untuk rekomendasi profesi dengan menggunakan Big Five Personality sebagai parameter.

\section{METODOLOGI PENELITIAN}

Dalam perhitungan FIS Tsukamoto, harus ditentukan terlebih dahulu nilai input dari seorang individu, yaitu dengan sebuah tes kepribadian butir butir dimensi Big Five Personality oleh John, (1990) yang diterjemahkan oleh Ramdhani, (2012) dan ditentukan range tiap dimensi untuk menggambarkan fungsi keanggotaan dalam FIS Tsukamoto yang disajikan pada Tabel 1.Dalam penelitian ini, tes Big Five Personality dijalankan menggunakan bahasa pemrograman php, tes tersebut akan menampilkan daftar pertanyaan sesuai dengan Tabel 1, menggunakan pilihan jawaban sebagai berikut :

$$
\begin{aligned}
& 1=\text { Sangat Tidak Setuju } \\
& 2=\text { Tidak Setuju } \\
& 3=\text { Netral } \\
& 4=\text { Setuju } \\
& 5=\text { Sangat Setuju }
\end{aligned}
$$

Adapun pilihan jawaban tersebut didapatkan dari Big Five Personality Test oleh ipip.ori.org, nilai yang didapatkan dari Big Five Personality memiliki range 0-40 pada setiap dimensi dari Big Five Personality, yaitu Extraversion, Aggreableness, Conscentiousness, Neuroticm, dan Opennes. Untuk skor penilaian didapatkan dengan melakukan perhitungan dengan menggunakan rumus yang digunakan oleh ipip.ori.org dalam mendapatkan nilai Big Five Personality.

Pada penelitian ini digunakan sistem inferensi Fuzzy Tsukamoto yang akan menggambarkan hubungan input dan output dengan aturan IF-THEN, yang nilai outputnya didapatkan dari acuan Top Ranked Personality - Based Work Styles for 22 Job Families (Sackett, 2014). Proses sistem inferensi 
Fuzzy Tsukamoto memiliki beberapa proses yaitu fuzzifikasi, sistem inferensi, dan defuzzifikasi

Tabel 1. Butir - Butir dimensi Big Five Personality

\begin{tabular}{|c|c|c|c|}
\hline Dimensi & Variabel & Range & $\begin{array}{c}\text { Range } \\
\text { Total }\end{array}$ \\
\hline \multirow{9}{*}{ Extraversion } & Banvak Bicara & $0-5$ & \multirow{9}{*}{$0-40$} \\
\hline & Tertutup & $0-5$ & \\
\hline & Penuh Aktifitas & $0-5$ & \\
\hline & Membangkitkan banyak antusiasme & $0-5$ & \\
\hline & Cenderung Pendiam & $0-5$ & \\
\hline & Mempunyai Kepribadian asertif & $0-5$ & \\
\hline & Terkadang malu, segan & $0-5$ & \\
\hline & Suka bergaul & $0-5$ & \\
\hline & $\begin{array}{l}\text { Seorang yang cenderung mencari } \\
\text { kesalahan orang lain }\end{array}$ & $0-5$ & \\
\hline \multirow{9}{*}{$\begin{array}{l}\text { Aggreable } \\
\text { ness }\end{array}$} & $\begin{array}{l}\text { Suka menolong dan tidak egois pada } \\
\text { orang lain }\end{array}$ & $0-5$ & \multirow{9}{*}{$0-40$} \\
\hline & $\begin{array}{l}\text { Memulai pertengkaran dengan orang } \\
\text { lain }\end{array}$ & $0-5$ & \\
\hline & Mempunyai sifat pemaaf & $0-5$ & \\
\hline & Pada umumnya dapat dipercaya & $0-5$ & \\
\hline & Bisa dingin dan menyendiri & $0-5$ & \\
\hline & $\begin{array}{l}\text { Memberi perhatian dan baik hati } \\
\text { kepada hampir setiap orang }\end{array}$ & $0-5$ & \\
\hline & Terkadang kasar terhadap orang lain & $0-5$ & \\
\hline & Menuntaskan pekerjaan & $0-5$ & \\
\hline & Kadang - kadang bisa sembrono & $0-5$ & \\
\hline \multirow{9}{*}{$\begin{array}{l}\text { Conscentious } \\
\text { ness }\end{array}$} & Menuntaskan Pekerjaan & $0-5$ & \multirow{9}{*}{$0-40$} \\
\hline & $\begin{array}{l}\text { Kadang - Kadang bisa } \\
\text { sembrono }\end{array}$ & $0-5$ & \\
\hline & Seorang pekerja yang handal & $0-5$ & \\
\hline & Cenderung tidak teratur & $0-5$ & \\
\hline & Cenderung pemalas & $0-5$ & \\
\hline & Gigih sampai tugas diselesaikan & $0-5$ & \\
\hline & $\begin{array}{l}\text { Mengerjakan sesuatu secara } \\
\text { efisien }\end{array}$ & $0-5$ & \\
\hline & $\begin{array}{l}\text { Membuat rencana -rencana dan } \\
\text { melaksanakannya }\end{array}$ & $0-5$ & \\
\hline & Mudah kacau pikiran & $0-5$ & \\
\hline \multirow{8}{*}{ Neuroticm } & $\begin{array}{l}\text { Santai, mengatasi stress dengan } \\
\text { baik. }\end{array}$ & $0-5$ & \multirow{8}{*}{$0-40$} \\
\hline & Bisa tegang & $0-5$ & \\
\hline & Terlalu khawatir & $0-5$ & \\
\hline & Stabil secara emosional. & $0-5$ & \\
\hline & Tidak mudah marah & & \\
\hline & Bisa murung & $0-5$ & \\
\hline & $\begin{array}{l}\text { Tetap tenang dalam situasi - } \\
\text { situasi tegang }\end{array}$ & $0-5$ & \\
\hline & Mudah gugup & $0-5$ & \\
\hline \multirow{9}{*}{ Opennes } & $\begin{array}{l}\text { Ingin tahu tentang banyak hal } \\
\text { yang berbeda }\end{array}$ & $0-5$ & \\
\hline & $\begin{array}{l}\text { Banyak akal, seorang pemikir } \\
\text { yang serius }\end{array}$ & $0-5$ & \\
\hline & Memiliki imajinasi aktif & $0-5$ & \\
\hline & Berdaya cipta & $0-5$ & \\
\hline & $\begin{array}{l}\text { Menghargai pengalaman- } \\
\text { pengalaman artistik, estetik }\end{array}$ & $0-5$ & \\
\hline & Lebih suka pekerjaan yang rutin & $0-5$ & \\
\hline & $\begin{array}{l}\text { Suka merefleksi, memainkan } \\
\text { gagasan }\end{array}$ & $0-5$ & \\
\hline & $\begin{array}{l}\text { Mempunyai sedikit minat } \\
\text { artistik }\end{array}$ & $0-5$ & \\
\hline & $\begin{array}{l}\text { Pintar dalam seni,musik / } \\
\text { kesusasteraan }\end{array}$ & $0-5$ & \\
\hline
\end{tabular}

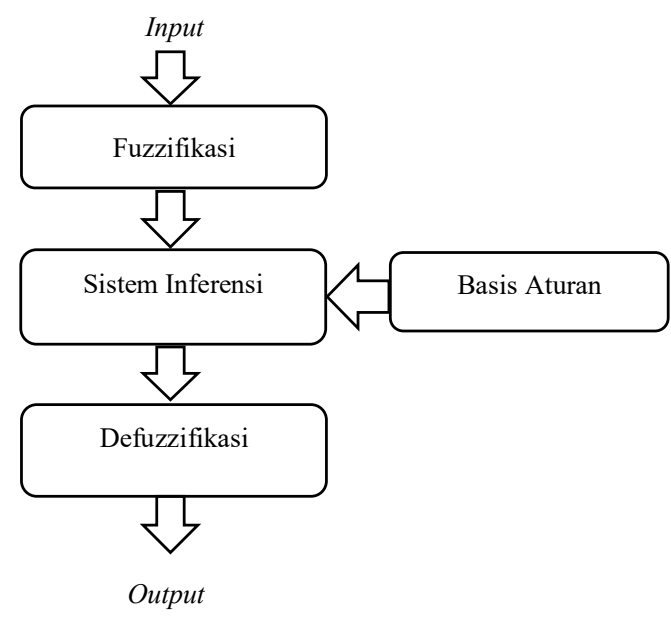

Gambar 1. Proses Logika Fuzzy

\subsection{Fuzzifikasi}

Proses fuzzifikasi merupakan perhitungan dari nilai crisp (tegas) dari sebuah input menjadi variabel linguistik berdasarkan derajat keanggotaan tertentu. Dalam penelitian ini terdapat 5 himpunan fuzzy yang terdiri dari Extraversion, Aggreableness, Conscen tiousness, Neuroticm, dan Opennes. Adapun fungsi keanggotaan himpunan fuzzy seperti berikut :

\subsubsection{Himpunan Fuzzy Input}

Pada variabel Extraversion, Aggreableness, Conscentiousness, Neuroticm, dan Opennes terdapat 3 himpunan fuzzy, yaitu rendah, sedang, dan tinggi. Dan persamaan 1, 2, 3 merupakan hasil dari pembentukan fungsi keanggotaan Extraversion.

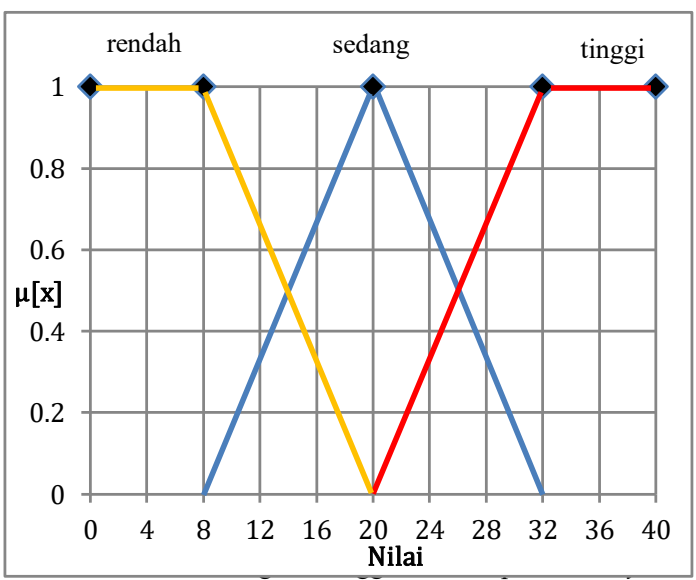

Gambar 2. Fungsi Keanggotaan Himpunan Fuzzy

Derajat keanggotaan rendah :

$$
\operatorname{\mu rendah}(x)=\left\{\begin{array}{cc}
0 ; & x \leq 8 \\
\frac{(20-x)}{(20-8)} & 8<x<20 \\
0 ; & x=20
\end{array}\right.
$$


Derajat keanggotaan sedang :

$$
\mu \text { sedang }(x)=\left\{\begin{array}{cc}
0 ; & \\
\frac{(x-8)}{(20-8)} & x \leq 8 \\
1 ; & <x<20 \\
\frac{(32-x)}{(32-20)} & x=20 \\
0 ; & x \geq 32
\end{array}\right.
$$

Derajat keanggotaan tinggi :

$$
\mu \operatorname{tinggi}(x)=\left\{\begin{array}{cc}
0 ; & x \leq 20 \\
\frac{(x-20)}{(32-20)} & 20<x<32 \\
1 ; & x \geq 32
\end{array}\right.
$$

\subsubsection{Himpunan Fuzzy Output}

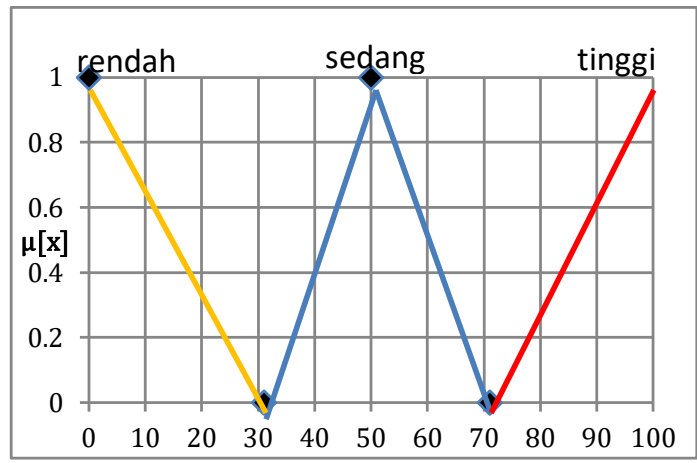

Gambar 3. Fungsi Keanggotaan Output

Adapun jenis profesi yang akan direkomendasi kan sebagai output merupakan 22 job families yang didapatkan dari $O * N E T$ Database yang digambarkan pada Tabel 2. (Sackett, 2014).

\subsection{Sistem Inferensi}

Sistem Inferensi proses pengkonversian input fuzzy menggunakan aturan "If - Then" yang akan menjadi output fuzzy (berupa keputusan). Dalam proses sistem inferensi dilakukan penentuan variabel output untuk sistem rekomendasi profesi. Dalam proses sistem inferensi fuzzy, terlebih dahulu ditentukan nilai batasan fungsi keanggotaan yang akan digunakan sebagai acuan dalam inputan nilai setiap dimensi kepribadian.

Adapun aturan yang terbentuk didapatkan dari rumus kombinasi $3^{5}=243$ Aturan, untuk mendapatkan hasil output digunakan acuan Top Ranked Personality- Based Work Styles for 22 Job Families (Sackett, 2014).

\subsection{Defuzzifikasi}

Merupakan langkah akhir dari proses FIS Tsukamoto. Defuzzifikasi merupakan suatu proses konversi output fuzzy dari sistem inferensi kedalam bentuk crisp (tegas). Dalam tahap Defuzzifikasi, terdapat proses konversi output fuzzy dari sistem inferensi kedalam bentuk tegas (Crisp).

\begin{tabular}{|c|c|c|}
\hline No. & Job family & Kode \\
\hline 1. & Computer and Mathematical & $\bar{A}$ \\
\hline 2. & Architecture and Engineering & $\mathrm{B}$ \\
\hline 3. & $\begin{array}{l}\text { Food Preparation and Serving } \\
\text { Related }\end{array}$ & $\mathrm{C}$ \\
\hline 4. & $\begin{array}{l}\text { Arts, Design, Entertainment, } \\
\text { Sports, and Media }\end{array}$ & $\mathrm{D}$ \\
\hline 5. & Health Care Support & $\mathrm{E}$ \\
\hline 6. & $\begin{array}{l}\text { Building and Grounds Cleaning } \\
\text { and } \\
\text { Maintenance }\end{array}$ & $\mathrm{F}$ \\
\hline 7. & Construction and Extraction & G \\
\hline 8. & Production & $\mathrm{H}$ \\
\hline 9. & $\begin{array}{l}\text { Office and Administrative } \\
\text { Support }\end{array}$ & I \\
\hline 10. & $\begin{array}{l}\text { Installation, Maintenance, and } \\
\text { Repair }\end{array}$ & $\mathrm{J}$ \\
\hline 11. & Management & $\mathrm{K}$ \\
\hline 12. & Education, Training, and Library & $\mathrm{L}$ \\
\hline 13. & Sales and Related & M \\
\hline 14. & Personal Care and Service & $\mathrm{N}$ \\
\hline 15. & Farming, Fishing, and Forestry & $\mathrm{O}$ \\
\hline 16. & $\begin{array}{l}\text { Transportation and Material } \\
\text { Moving }\end{array}$ & $P$ \\
\hline 17. & $\begin{array}{l}\text { Life, Physical, and Social } \\
\text { Science }\end{array}$ & Q \\
\hline 18. & $\begin{array}{l}\text { Business and Financial } \\
\text { Operations }\end{array}$ & $\mathrm{R}$ \\
\hline 19. & Legal & $\mathrm{S}$ \\
\hline 20. & $\begin{array}{l}\text { Health Care Practitioners and } \\
\text { Technical }\end{array}$ & $\mathrm{T}$ \\
\hline 21. & Community and Social Services & $\mathrm{U}$ \\
\hline 22. & Protective Service & V \\
\hline
\end{tabular}

Tabel 2. Himpunan Fuzzy Hasil Output

Tabel 3. Himpunan fuzzy dan domain dari variabel input

\begin{tabular}{lcc}
\hline \multicolumn{1}{c}{ Variabel } & Domain & Nilai Linguistik \\
\hline \multirow{2}{*}{ Extraversion } & $0-20$ & Rendah \\
& $12-28$ & Sedang \\
& $20-40$ & Tinggi \\
Aggreableness & $0-20$ & Rendah \\
& $12-28$ & Sedang \\
Conscentiousness & $20-40$ & Tinggi \\
& $0-20$ & Rendah \\
Neuroticm & $12-28$ & Sedang \\
& $20-40$ & Tinggi \\
& $0-20$ & Rendah \\
& $12-28$ & Sedang \\
Opennes & $20-40$ & Tinggi \\
& $0-20$ & Rendah \\
& $12-28$ & Sedang \\
& $20-40$ & Tinggi \\
\hline
\end{tabular}


Tabel 4. Basis Aturan

\begin{tabular}{|c|c|c|c|c|c|c|}
\hline No. & extra & agree & cons & neuro & open & $\begin{array}{r}\text { Job } \\
\text { family }\end{array}$ \\
\hline 1. & rendah & sedang & sedang & rendah & tinggi & \\
\hline 2. & rendah & sedang & sedang & sedang & tinggi & \\
\hline 3. & rendah & sedang & sedang & tinggi & tinggi & \\
\hline 4. & sedang & sedang & sedang & rendah & tinggi & \\
\hline 5. & sedang & sedang & sedang & sedang & tinggi & $A$ \\
\hline 6. & sedang & sedang & sedang & tinggi & tinggi & \\
\hline 7. & tinggi & sedang & sedang & rendah & tinggi & \\
\hline 8. & tinggi & sedang & sedang & sedang & tinggi & \\
\hline 9. & tinggi & sedang & sedang & tinggi & tinggi & \\
\hline 10. & rendah & sedang & tinggi & sedang & tinggi & $R$ \\
\hline 11. & sedang & sedang & tinggi & sedang & tinggi & $B$ \\
\hline 12. & rendah & tinggi & sedang & sedang & rendah & \\
\hline 13. & rendah & tinggi & sedang & sedang & sedang & \\
\hline 14. & rendah & tinggi & sedang & sedang & tinggi & \\
\hline 15. & sedang & tinggi & sedang & sedang & rendah & \\
\hline 16. & sedang & tinggi & sedang & sedang & sedang & $C$ \\
\hline 17. & sedang & tinggi & sedang & sedang & tinggi & \\
\hline 18. & tinggi & tinggi & sedang & sedang & rendah & \\
\hline 19. & tinggi & tinggi & sedang & sedang & sedang & \\
\hline 20. & tinggi & tinggi & sedang & sedang & tinggi & \\
\hline 21. & rendah & rendah & tinggi & tinggi & tinggi & \\
\hline 22. & rendah & sedang & tinggi & tinggi & tinggi & \\
\hline 23. & rendah & tinggi & tinggi & tinggi & tinggi & \\
\hline 24. & sedang & rendah & tinggi & tinggi & tinggi & \\
\hline 25. & sedang & sedang & tinggi & tinggi & tinggi & $D$ \\
\hline 26. & sedang & tinggi & tinggi & tinggi & tinggi & \\
\hline 27. & sedang & rendah & tinggi & tinggi & tinggi & \\
\hline 28. & sedang & sedang & tinggi & tinggi & tinggi & \\
\hline 29. & sedang & tinggi & tinggi & tinggi & tinggi & \\
\hline 30. & rendah & sedang & tinggi & tinggi & rendah & \\
\hline 31. & rendah & sedang & tinggi & tinggi & sedang & \\
\hline 32. & rendah & sedang & tinggi & tinggi & tinggi & \\
\hline 33. & sedang & sedang & tinggi & tinggi & rendah & \\
\hline 34. & sedang & sedang & tinggi & tinggi & sedang & $E$ \\
\hline 35. & sedang & sedang & tinggi & tinggi & tinggi & \\
\hline 36. & tinggi & sedang & tinggi & tinggi & rendah & \\
\hline 37. & tinggi & sedang & tinggi & tinggi & sedang & \\
\hline 38. & tinggi & sedang & tinggi & tinggi & tinggi & \\
\hline 39. & rendah & sedang & tinggi & sedang & rendah & \\
\hline 40. & rendah & sedang & tinggi & sedang & sedang & \\
\hline 41. & rendah & sedang & tinggi & sedang & tinggi & \\
\hline 42. & sedang & sedang & tinggi & sedang & rendah & \\
\hline 43. & sedang & sedang & tinggi & sedang & sedang & $F$ \\
\hline 44. & sedang & sedang & tinggi & sedang & tinggi & \\
\hline 45. & tinggi & sedang & tinggi & sedang & rendah & \\
\hline 46. & tinggi & sedang & tinggi & sedang & sedang & \\
\hline 47. & tinggi & sedang & tinggi & sedang & tinggi & \\
\hline
\end{tabular}

\begin{tabular}{|c|c|c|c|c|c|c|}
\hline No. & extra & agree & cons & neuro & open & $\begin{array}{r}\text { Job } \\
\text { amily }\end{array}$ \\
\hline 48. & rendah & sedang & tinggi & sedang & rendah & $G$ \\
\hline 49. & rendah & sedang & tinggi & sedang & sedang & \\
\hline 50. & rendah & sedang & tinggi & sedang & tinggi & \\
\hline 51. & sedang & sedang & tinggi & sedang & rendah & \\
\hline 52. & sedang & sedang & tinggi & sedang & sedang & \\
\hline 53. & sedang & sedang & tinggi & sedang & tinggi & \\
\hline 54. & tinggi & sedang & tinggi & sedang & rendah & \\
\hline 55. & tinggi & sedang & tinggi & sedang & sedang & \\
\hline 56. & tinggi & sedang & tinggi & sedang & tinggi & \\
\hline 57. & rendah & tinggi & tinggi & sedang & rendah & \\
\hline 58. & rendah & tinggi & tinggi & sedang & sedang & \\
\hline 59. & rendah & tinggi & tinggi & sedang & tinggi & \\
\hline 60. & tinggi & tinggi & tinggi & sedang & rendah & \\
\hline 61. & tinggi & tinggi & tinggi & sedang & sedang & \\
\hline 62. & tinggi & tinggi & tinggi & sedang & tinggi & \\
\hline 63. & rendah & tinggi & tinggi & rendah & rendah & \\
\hline 64. & rendah & tinggi & tinggi & rendah & sedang & $H$ \\
\hline 65. & rendah & tinggi & tinggi & rendah & tinggi & \\
\hline 66. & rendah & tinggi & tinggi & tinggi & rendah & \\
\hline 67. & rendah & tinggi & tinggi & tinggi & sedang & \\
\hline 68. & rendah & tinggi & sedang & tinggi & rendah & $J$ \\
\hline 69. & rendah & tinggi & sedang & tinggi & tinggi & \\
\hline 70. & sedang & sedang & tinggi & rendah & rendah & \\
\hline 71. & sedang & sedang & tinggi & rendah & sedang & $K$ \\
\hline 72. & sedang & sedang & tinggi & rendah & tinggi & \\
\hline 73. & sedang & sedang & sedang & sedang & sedang & \\
\hline 74. & sedang & sedang & rendah & sedang & sedang & \\
\hline 74. & sedang & sedang & sedang & tinggi & rendah & $L$ \\
\hline 75. & sedang & sedang & sedang & tinggi & sedang & \\
\hline 76. & sedang & tinggi & sedang & tinggi & sedang & \\
\hline 77. & sedang & tinggi & tinggi & tinggi & sedang & $M$ \\
\hline 79. & rendah & rendah & tinggi & sedang & sedang & \\
\hline 80. & rendah & rendah & tinggi & sedang & tinggi & $O$ \\
\hline 81. & rendah & rendah & tinggi & tinggi & sedang & \\
\hline 82. & rendah & sedang & sedang & sedang & rendah & \\
\hline 83. & rendah & sedang & sedang & sedang & sedang & $P$ \\
\hline $84 .$. & sedang & tinggi & tinggi & tinggi & tinggi & $Q$ \\
\hline 85. & sedang & tinggi & tinggi & tinggi & sedang & $R$ \\
\hline 86. & rendah & tinggi & tinggi & tinggi & sedang & $\bar{S}$ \\
\hline 87. & rendah & tinggi & tinggi & tinggi & rendah & $T$ \\
\hline 88. & sedang & sedang & sedang & tinggi & rendah & $\bar{U}$ \\
\hline 89. & sedang & sedang & sedang & tinggi & sedang & $\bar{V}$ \\
\hline
\end{tabular}

Untuk melakukan perhitungan Fuzzy Inference System (FIS) Tsukamoto, diperlukan value dari nilai input yang didapatkan dari tes Big Five Personality, adapun contoh nilai input untuk perhitungan tersebut disajikan pada Tabel 5 .

Tabel 5. Contoh Permasalahan

\begin{tabular}{lc}
\hline \multicolumn{1}{c}{ Variabel Input } & Nilai Input \\
\hline Extraversion & $\mathbf{3 5}$ \\
Agreeableness & $\mathbf{2 5}$ \\
Constiousness & $\mathbf{2 2}$ \\
Neuroticm & $\mathbf{1 7}$ \\
Opennes & $\mathbf{2 8}$ \\
\hline
\end{tabular}




\subsection{Fuzzifikasi}

Setelah didapatkan nilai input (crisp) maka proses awal adalah mengelompokkan nilai input tersebut kedalam bentuk fuzzy dengan variabel linguistik sebagai berikut.

\section{a. Variabel Linguistik Extraversion}

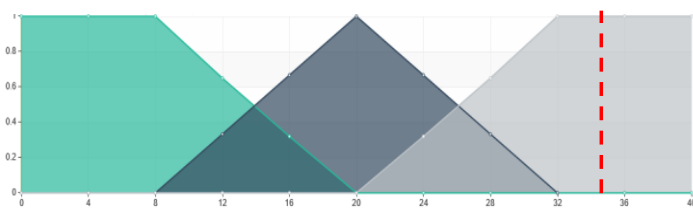

Gambar 4. Fungsi Keanggotaan Extraversion

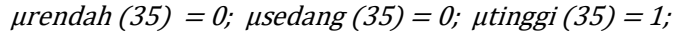

Nilai input crisp untuk Extraversion adalah 35 yang berada pada variabel linguistik tinggi. Adapun nilai input 35 tersebut berada pada derajat keanggotaan 1 untuk tinggi, dan pada variabel linguistik rendah dan sedang memiliki derajat keanggotaan 0 .

\section{b. Variabel Linguistik Agreeableness}

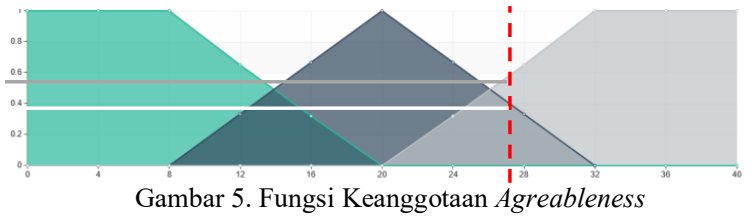

$\operatorname{\mu rendah}(25)=0$

$\mu$ sedang $(25)=\frac{(b-x)}{(b-a)}=\frac{(32-25)}{(32-20)}=\frac{7}{12}=0,583$

utinggi (25) $=\frac{(x-a)}{(b-a)}=\frac{(25-20)}{(32-20)}=\frac{5}{12}=0,417$

Nilai input crisp untuk Agreeableness adalah 25 yang berada pada variabel lingustik sedang, dan variabel linguistik tinggi. Derajat keanggotaan 0 untuk variabel linguistik rendah, derajat keanggotaan 0,583 pada variabel linguistik sedang, dan derajat keanggotaan 0,417 untuk variabel linguistik tinggi.

\section{c. Variabel Linguistik Conscentiousness}

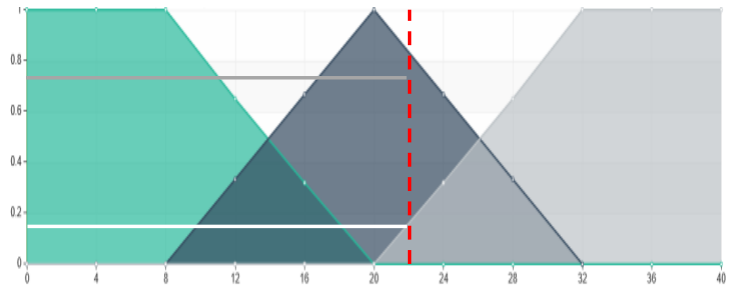

Gambar 6. Fungsi Keanggotaan Conscentiousness

urendah (22) $=0$

$\mu$ sedang (22) $=\frac{(b-x)}{(b-a)}=\frac{(22-25)}{(32-20)}=\frac{10}{12}=0,883$

ptinggi $(22)=\frac{(x-a)}{(b-a)}=\frac{(22-20)}{(32-20)}=\frac{2}{12}=0,167$
Nilai input crisp untuk Conscentiousness adalah 22 yang berada pada variabel lingustik sedang, dan variabel linguistik tinggi. Derajat keanggotaan 0 untuk variabel linguistik rendah, derajat keanggotaan 0,833 pada variabel linguistik sedang, dan derajat keanggotaan 0,167 untuk variabel linguistik tinggi.

\section{d. Variabel Linguistik Neuroticm}

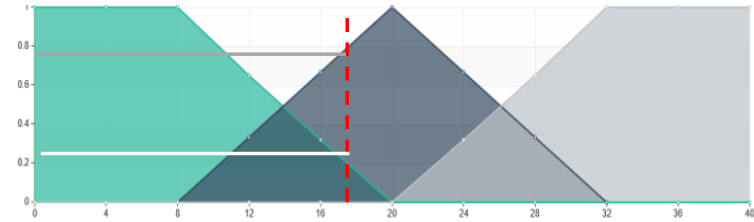

Gambar 7. Fungsi Keanggotaan Neuroticm

urendah (17) $=\frac{(b-x)}{(b-a)}=\frac{(20-17)}{(20-8)}=\frac{3}{12}=0,25$

$\operatorname{sedang}(17)=\frac{(b-x)}{(b-a)}=\frac{(17-8)}{(20-8)}=\frac{9}{12}=0,75$

$\mu$ tinggi(17) $=0$

Nilai input crisp untuk Neuroticm adalah 17 yang berada pada variabel lingustik rendah, dan variabel linguistik sedang. Derajat keanggotaan 0,25 pada variabel linguistik rendah, derajat keanggotaan 0,75 untuk variabel linguistik sedang, dan derajat keanggotaan 0 untuk variabel linguistik tinggi.

\section{e. Variabel Linguistik Opennes}

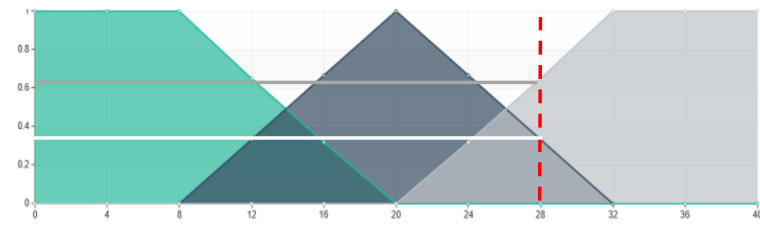

Gambar 8. Fungsi Keanggotaan Opennes

$$
\begin{aligned}
& \text { Arendah }(28)=0 \\
& \mu \text { sedang }(28)=\frac{(b-x)}{(b-a)}=\frac{(20-17)}{(20-8)}=\frac{3}{12}=0,333 \\
& \mu \text { tinggi }(28)=\frac{(x-a)}{(b-a)}=\frac{(17-8)}{(20-8)}=\frac{9}{12}=0,667
\end{aligned}
$$

Nilai input crisp untuk Opennes adalah 28 yang berada pada variabel lingustik sedang, dan variabel linguistik tinggi. Derajat keanggotaan 0 untuk variabel linguistik rendah, derajat keanggotaan 0,333 pada variabel linguistik sedang, dan derajat keanggotaan 0,667 untuk variabel linguistik tinggi.

\subsection{Sistem Inferensi}

Sistem inferensi dalam rekomendasi profesi ini menggunakan aturan "IF-THEN" . Adapun jumlah aturan fuzzy didapatkan dari persamaan 1 .

Kombinasi variabel linguistik

$$
\frac{n !}{(n-k) ! k !}=\frac{3 !}{(3-1) ! 1 !}=3
$$


$3^{5}=243$ Aturan

Dari aturan fuzzy tersebut akan dicari aturan yang sesuai dengan hasil dari proses fuzzifikasi sebelumnya. Untuk contoh permasalahan tersebut didapatkan 16 aturan yang sesuai, adapun hasil aturan disajikan pada Tabel 6 .

Tabel 6. Aturan Fuzzy yang sesuai

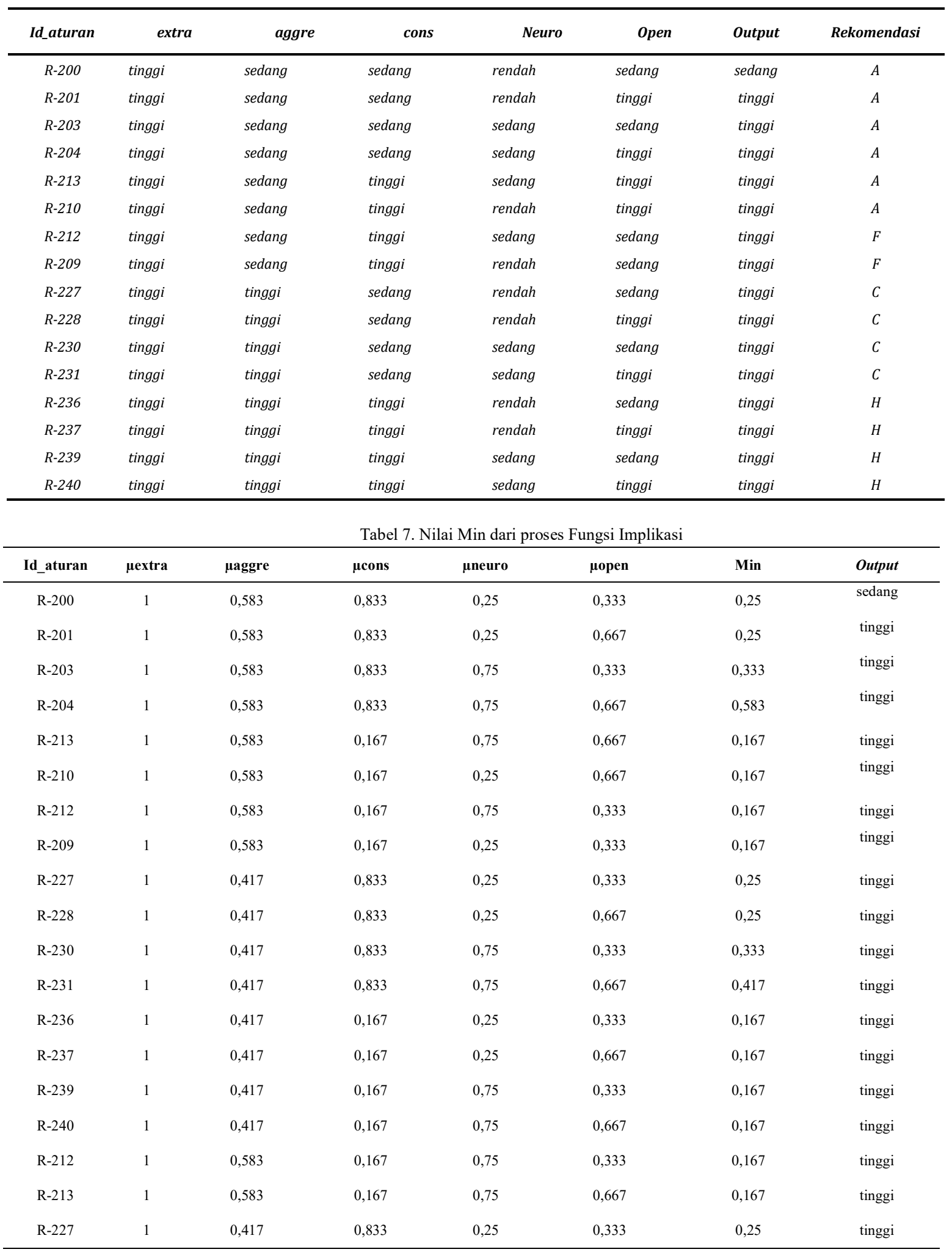




\subsubsection{Aplikasi Fungsi Implikasi}

Setelah mendapatkan aturan yang sesuai, maka langkah selanjutnya adalah mengambil derajat keanggotaan minimum dari setiap nilai linguistik yang ada pada setiap aturan yang sesuai. Adapun dapat disajikan pada Tabel 7.

Pada Tabel 7. akan dipilih nilai minimum, yang akan menjadi ukuran nilai $\mu$ Output yang akan menentukan seberapa besar kecocokan suatu output. Selanjutnya adalah menentukan nilai crisp $\mathrm{z}$ dari setiap aturan, dimana nilai crisp $\mathrm{z}$ akan digunakan dalam proses selanjutnya yaitu proses defuzzifikasi. Adapun rumus untuk menghitung nilai crisp $\mathrm{z}$ disajikan pada persamaan 2 .

$z=z \max -\propto n(z \max -z \min )$

Untuk memperoleh nilai zmax dan zmin, terlebih dahulu dibuat grafik batas keanggotaan untuk nilai $\mu$ output berdasarkan rule yang telah didapatkan.

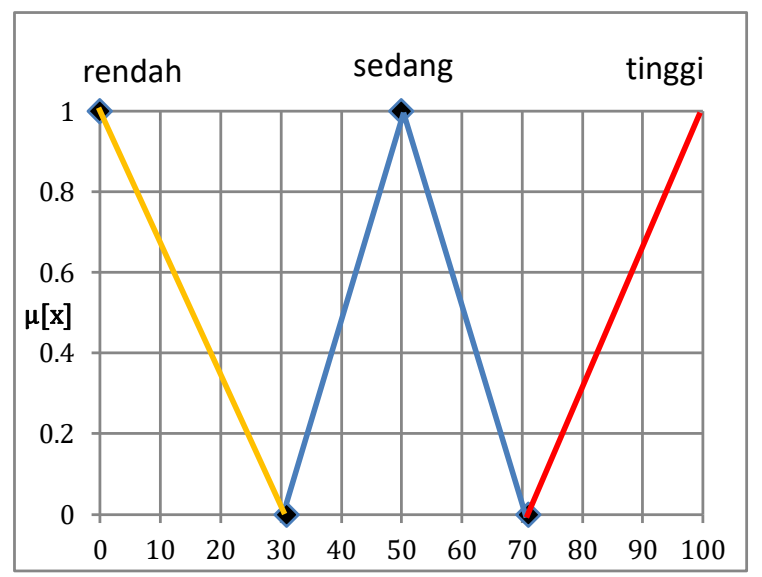

Gambar 9. Fungsi Keanggotaan Output

Setelah mengetahui nilai zmin dan zmax dari masing masing aturan yang sesuai, pada Tabel 8. akan disajikan hasil perhitungan nilai $\mathrm{z}$ yang akan digunakan untuk tahap selanjutnya yaitu defuzzifikasi.

\subsection{Defuzzifikasi}

Metode defuzzifikasi yang digunakan adalah metode rata - rata terpusat pada persamaan 3 .

$$
Z=\left(\frac{\left.\alpha_{1} \times z_{1}+\alpha_{n} \times z_{n}\right)}{\sum \alpha_{1 . . n}}\right)
$$

\section{$Z=\quad \mathbf{8 8 . 9 0 9 2 8 5 3 5 7 3 2 1}$}

Maka output rekomendasi profesi yang mendekati nilai z adalah A yaitu Computer and Mathematical, dengan rincian yang disajikan dalam Tabel 9.
Tabel 8. Nilai Crisp z

\begin{tabular}{|c|c|c|c|c|c|}
\hline Id_aturan & $\begin{array}{c}\alpha- \\
\text { predikat }\end{array}$ & zmin & zmax & $\mathbf{z}$ & Rekomendasi \\
\hline $\mathrm{R}-200$ & 0,25 & 30 & 70 & 60 & A \\
\hline $\mathrm{R}-201$ & 0,25 & 70 & 100 & 92,5 & A \\
\hline R-203 & 0,333 & 70 & 100 & 90,01 & A \\
\hline $\mathrm{R}-204$ & 0,583 & 70 & 100 & 82,51 & A \\
\hline $\mathrm{R}-213$ & 0,167 & 70 & 100 & 94,99 & A \\
\hline $\mathrm{R}-210$ & 0,167 & 70 & 100 & 94,99 & A \\
\hline $\mathrm{R}-212$ & 0,167 & 70 & 100 & 94,99 & F \\
\hline R-209 & 0,167 & 70 & 100 & 94,99 & F \\
\hline $\mathrm{R}-227$ & 0,25 & 70 & 100 & 92,5 & $\mathrm{C}$ \\
\hline $\mathrm{R}-228$ & 0,25 & 70 & 100 & 92,5 & $\mathrm{C}$ \\
\hline $\mathrm{R}-230$ & 0,333 & 70 & 100 & 92,5 & $\mathrm{C}$ \\
\hline $\mathrm{R}-231$ & 0,417 & 70 & 100 & 87,49 & $\mathrm{C}$ \\
\hline $\mathrm{R}-236$ & 0,167 & 70 & 100 & 94,99 & $\mathrm{H}$ \\
\hline $\mathrm{R}-237$ & 0,167 & 70 & 100 & 94,99 & $\mathrm{H}$ \\
\hline $\mathrm{R}-239$ & 0,167 & 70 & 100 & 94,99 & $\mathrm{H}$ \\
\hline $\mathrm{R}-240$ & 0,167 & 70 & 100 & 94,99 & $\mathrm{H}$ \\
\hline
\end{tabular}

$\sum \alpha n=4.002$

Tabel 9. Rincian Hasil Ouput

\begin{tabular}{ccccccc}
\hline Id_Aturan & $\begin{array}{c}\boldsymbol{\alpha}- \\
\text { predikat }\end{array}$ & zmin & zmax & $\mathbf{z}$ & Output & Rek. \\
\hline R-203 & 0,333 & 70 & 100 & $\mathbf{9 0 , 0 1}$ & tinggi & A \\
\hline
\end{tabular}

\section{Pengujian Akurasi Sistem}

Pada tahap ini akan dilakukan pengujian akurasi sistem yang dilakukan untuk tujuan mengetahui seberapa besar akurasi sistem dari rekomendasi profesi ini dengan cara melakukan pengujian terhadap 243 data aturan.

Adapun pada Tabel 10. disajikan data uji sejumlah 22 data berikut dengan hasil output yang berasal dari rekomendasi sistem, dan aturan didapatkan berdasarkan acuan Top Ranked Personality- Based Work Styles for 22 Job Families (Sackett, 2014) . 
Tabel 10. Pengujian Akurasi Sistem

\begin{tabular}{|c|c|c|c|c|c|c|c|}
\hline Extra & Agree & Cons & Neuro & Open & Output & Aturan & Nilai \\
\hline 40 & 40 & 35 & 40 & 31 & $\overline{\mathbf{A}}$ & $\mathbf{A}$ & 1 \\
\hline 35 & 25 & 22 & 17 & 28 & $\mathbf{A}$ & A & 1 \\
\hline 29 & 29 & 18 & 24 & 25 & B & C & 0 \\
\hline 37 & 33 & 31 & 27 & 24 & D & D & 1 \\
\hline 16 & 18 & 15 & 15 & 19 & $\mathbf{E}$ & $\mathbf{L}$ & 0 \\
\hline 28 & 26 & 26 & 29 & 24 & $\mathbf{F}$ & D & 0 \\
\hline 38 & 23 & 32 & 32 & 36 & C & C & 1 \\
\hline 34 & 33 & 27 & 35 & 32 & D & D & 1 \\
\hline 39 & 24 & 15 & 29 & 12 & $\mathbf{A}$ & $\mathbf{A}$ & 1 \\
\hline 28 & 18 & 23 & 21 & 22 & $\mathbf{A}$ & $\mathbf{A}$ & 1 \\
\hline 22 & 25 & 25 & 22 & 22 & C & $\mathbf{L}$ & 0 \\
\hline 24 & 25 & 25 & 24 & 26 & $\mathbf{A}$ & $\mathbf{A}$ & 1 \\
\hline 24 & 27 & 28 & 19 & 27 & $\mathbf{H}$ & B & 0 \\
\hline 34 & 34 & 31 & 32 & 33 & D & D & 1 \\
\hline 27 & 23 & 29 & 28 & 35 & C & C & 1 \\
\hline 25 & 25 & 30 & 33 & 34 & C & C & 1 \\
\hline 27 & 23 & 30 & 31 & 35 & B & $\mathbf{A}$ & 0 \\
\hline 34 & 38 & 30 & 32 & 36 & D & D & 1 \\
\hline 38 & 36 & 36 & 37 & 32 & D & D & 1 \\
\hline 26 & 19 & 24 & 32 & 36 & C & $\mathbf{A}$ & $\mathbf{0}$ \\
\hline 38 & 36 & 33 & 23 & 32 & D & D & 1 \\
\hline 40 & 28 & 33 & 29 & 26 & $\mathbf{F}$ & D & 0 \\
\hline & & & & & \multicolumn{2}{|c|}{ Total } & 14 \\
\hline
\end{tabular}

Keterangan :

$$
\begin{array}{ll}
\text { Extra } & =\text { Dimensi Extraversion } \\
\text { Agree } & =\text { Dimensi Agreeableness } \\
\text { Cons } & =\text { Dimensi Conscentiousness } \\
\text { Neuro } & =\text { Dimensi Neuroticm } \\
\text { Open }= & \text { Dimensi Opennes } \\
\text { Nilai }= & 1, \text { apabila sesuai } \\
& 0, \text { tidak sesuai }
\end{array}
$$

Berdasarkan Tabel 10. yang menunjukkan perbandingan antara hasil output sistem dengan perhitungan Fuzzy Inference System (FIS) Tsukamoto dan data aturan dengan 22 data uji dapat dihitung besarnya akurasi dengan perhitungan persamaan 4 .

$$
\begin{aligned}
\text { Nilai Akurasi } & =\frac{\text { Jumlah Data Akurat }}{\text { Jumlah Data }} \times 100 \% \\
& =\frac{14}{22} \times 100 \%=63 \%
\end{aligned}
$$

Akurasi sistem rekomendasi profesi berdasarkan Big Five Personality menggunakan Fuzzy Inference System (FIS) Tsukamoto berdasarkan 22 data uji memiliki tingkat keberhasilan yaitu sebesar $63 \%$.

\section{KESIMPULAN}

Dari hasil penelitian ini dapat disimpulkan bahwa metode Fuzzy Inference System (FIS) Tsukamoto dapat digunakan dalam sistem rekomendasi profesi berdasarkan Big Five Personality dengan tujuan untuk memberikan rekomendasi profesi yang tepat kepada seseorang berdasarkan nilai dimensi Big Five Personality.

Dalam penelitian ini, hasil output rekomendasi sistem ditentukan berdasarkan data aturan berdasarkan acuan Top Ranked Personality- Based Work Styles for 22 Job Families (Sackett, 2014). Hasil pengujian akurasi sistem rekomendasi didapatkan dari perbandingan hasil output sistem dan data aturan tersebut.

Berdasarkan hasil pengujian tersebut didapatkan nilai akurasi sebesar $63 \%$ dan nilai eror sebesar $37 \%$. Nilai eror tersebut disebabkan oleh penentuan fungsi keanggotaan yang belum optimal, Oleh karena itu, untuk penelitian selanjutnya dapat digunakan metode algoritma evolusi untuk menentukan fungsi keanggotaan yang optimal sehingga dapat menghasilkan nilai akurasi yang lebih baik, seperti yang telah dilakukan oleh Parewe, dkk (2018) yang melakukan Hibridisasi Logika Fuzzy dengan Algoritma Genetika yang terbukti dapat menghasilkan tingkat akurasi yang lebih akurat.

\section{DAFTAR PUSTAKA}

AMALIYAH, M., NOVIYANTO, F., 2013. Aplikasi Tes Kepribadian untuk Penempatan Karyawan Menggunakan Metode MBTI (Myerss-Briggs Type Indicator) Berbasis Web, Jurnal STI eISSN: 2338-5197 Volume 1 Nomor 2, Oktober 2013

GOLDBERG, L.T., 1981. Language and individual differences: The search for universal in personality lexicons. In L. Wheeler (ed.). Review of Personality and Social Psychology. 2, 141-165. Beverly hills, CA.: Sage Pub.

GOLDBERG, L. R., 1992. The development of markers for the Big-Five factor structure. Psychological Assessment 4, 26-42. doi:10.1037/1040-3590.4.1.26

HADI H. N., MAHMUDY W. F., 2015. Penilaian Prestasi Kinerja Pegawai Menggunakan Fuzzy.Jurnal Teknologi Informasi dan Ilmu Komputer (JTIIK) vol. 2, no. 1.

JOHN, O.,1990. The 'Big Five' factor taxonomy: Dimensions of personalityin the natural language and questionnaires. In. L.A. Pervin (Ed.), Handbook of personality: Theory and research (pp. 66100). New York: Guilford Press.

KUSUMADEWI, S., PURNOMO, H., 2013. Aplikasi Logika Fuzzy untuk Pendukung Keputusan, Graha Ilmu Yogyakarta. 
LARSON, L.M., ROTTINGHAUS P.J., BORGEN F.H., 2002. Meta - analyses of Big Six Interests and Big Five Personality Factors, Journal of Vocational Behavior 61, pp.217-239

MANSYUR, S. H., HARTATI, S., 2014. Prototipe Sistem Pakar Pendiagnosa Penyakit Karies Pada Gigi Menggunakan Fuzzy Inference System Dengan Metode Tsukamoto. Berkala Ilmiah MIPA, 24 (Vol 24, No 1 (2014)), 89-100.

PAREWE, A. M. A. K., MAHMUDY, W. F.,2016. Seleksi Calon Karyawan Menggunakan Metode Fuzzy Tsukamoto. Seminar Nasional Sistem Informasi Indonesia, 2-3 November 2015,1819.

PAREWE, A. M. A. K., dkk., 2018. Dental Disease Detection Using Hybrid Fuzzy Logic and Evolution Strategies. Journal of Telecommunication, Electronic and Computer Engineering Vol. 10 No. 1-8.

Q. D. NGUYEN, T. HUYNH, T. A. NGUYENHOANG., 2016. Adaptive methods for job recommendation based on user clustering. NICS 2016 - Proc. 2016 3rd Natl. Found. Sci. Technol. Dev. Conf. Inf. Comput. Sci., pp. 165 170.

RAMDHANI, N., 2012. Adaptasi Bahasa dan Inventory Big Five. Jurnal Psikologi volume 39, No. 2, Desember 2012 : 189-207. Universitas Gadjah Mada,Yogyakarta.

SACKETT, P. R., 2014. Which Personality Attributes Are Most Important in the Workplace. Perspectives on Psychological Science, 9(5), 538-551.

SEIBERT, S. E., \& KRAIMER, M. L., 2001. The Five-Factor Model of Personality and Career Success. Journal of Vocational Behavior 58 , $1-21$.

SOEPOMO, P., 2013. Aplikasi Tes Kepribadian untuk Penempatan Karyawan Menggunakan Metode MBTI (Myers-Briggs Type Indicator) Berbasis Web(Studi Kasus : PT . Winata Putra Mandiri), 1, 607-616.

WIDHIASTUTI, H., 2014. Big Five Personality sebagai Prediktor Kreativitas dalam Meningkatkan Kinerja Anggota Dewan. Jurnal Psikologi Volume 41, No. 1, Juni 2014: 115 133.Fakultas Psikologi Universitas Semarang.

WAHYUNI, I., MAHMUDY W. F., IRIANY A., 2016. Rainfall prediction in Tengger region Indonesia using Tsukamoto fuzzy inference system.Proc. - 2016 1st Int. Conf. Inf. Technol.
Inf. Syst. Electr. Eng. ICITISEE 2016, pp. 130135. 